\title{
Z generáció és a home office viszonya 2020-ban a COVID19 idején - Pilot kutatás eredményei
}

\author{
Csepregi Anikóa - Csanády Bettina ${ }^{b}$ \\ a Pannon Egyetem \\ bPécsi Tudományegyetem
}

\begin{abstract}
A TANULMÁNY CÉLJA
A tanulmány fókuszában a COVID19 járvány home office-ra (HO) való hatásának vizsgálata áll, 2020. március és december közötti időszakra vonatkozóan a $Z$ generációs munkavállalók szempontjából 3 régió tekintetében. Pilot kutatásunk célja feltárni a 1) HO alatt érzékelt teljesítménnyel kapcsolatos tényezők közötti kapcsolatot, 2) HO munkavégzéshez kapcsolódó munkavállalói előnyök és hátrányok TOP5 listájában mutatkozó eltéréseket földrajzi elhelyezkedés tekintetében, 3) munkavállalók HO-val kapcsolatos vélekedését földrajzi elhelyezkedés, végzettség és az elrendelt HO alkalmak száma alapján.
\end{abstract}

\begin{abstract}
ALKALMAZOTT MÓDSZERTAN
Pilot kutatásunk alapját egy, a 2021. februárjában végzett, kérdőíves felmérés adta, amellyel 3 régió 1-1 kiválasztott megyeszékhelynél (Budapest, Pécs, Székesfehérvár) $118 \mathrm{Z}$ generációs munkavállalónak, a fenti időszakra vonatkozó HO tapasztalatait vizsgáltuk. Az adatokon kereszttábla és szentimentelemzés mellett, TOP5 sorrend kialakítását és összehasonlítását is elvégeztük.
\end{abstract}

\section{LEGFONTOSABB EREDMÉNYEK}

A pilot kutatás során kapcsolat fedezhető fel a Z generációs munkavállalóknak a HO időszaka alatt érzékelt teljesítményhez köthető bizonyos tényezők között. A HO TOP5 előnyei tekintetében nem, hátrányai kapcsán viszont jelentősebb különbség látható a régiók összehasonlításában. Leginkább Székesfehérváron és Pécsett vélekednek pozitívan a HO-ról, akik érettségivel rendelkeznek, és akiknél csak egyszer rendelték el a HO-t. Negatívan a budapestiek, BSc vagy MSc végzettséggel rendelkezők és a több alkalommal HO-ban dolgozók viszonyultak a HO-hoz.
}

\section{GYAKORLATI JAVASLATOK}

Pilot kutatásként az eredmények hozzájárulhatnak a Z generációs munkavállalók HO alatti viselkedésének további vizsgálatához és jobb megértéséhez, azonban még korlátozottan alkalmasak messzemenő következtetések levonására. További kutatási irányként a jövőben, a minta elemszámát érdemes lenne növelni a kutatásnak más régiókra való kiterjesztésével, valamint összehasonlítani a $Z$ generációs munkavállalókra vonatkozó eredményeket más generációkkal (pl. Y generáció).

Kulcsszavak: COVID19, home office, kereszttábla elemzés, szentimentelemzés, Z generáció

DOI: 10.15170/MM.2021.55.03.05 


\section{BEVEZETÉS INTRODUCTION}

A 2019 év végen megjelenő COVID19 járvány gazdasági és társadalmi következményei súlyosan hatottak a világ valamennyi országára. A turizmusban, kereskedelemben, termelésben, munkaerőpiacon és még számos területen visszaesés következett be (Susskind et al. 2020). Barrot et al. (2021) megállapították továbbá, hogy egy 6 hetes társadalmi távolságtartás 5,6 \%-kal csökkentheti az éves GDPt. A KSH (2020) adatai alapján hazánkban a járvány helyzet alakulásával párhuzamosan nőtt a munkanélküliek száma is (2020 január: 3,4\%, augusztus: $4,8 \%)$.

A Magyar Kormány márciusban az Alaptörvény 53. cikke alapján veszélyhelyzetet hirdetett ki az ország egész területén. A 40/2020. (III. 11.) Korm. rendelet $1 . \S$ alapján 2020.03.11. és 2020.06.17 között veszélyhelyzet állt fenn. A járvány visszaszorításának érdekében korlátozások léptek életbe. A 71/2020 (III. 27.) Korm. rendelet 3.§ szerint a lakóhely elhagyására meghatározott alapos indokkal kerülhetett sor. A 1102/2020. (III. 14.) Korm. rendelet $1 . \S$ a) bekezdése alapján 2020.03.16. napjától az iskolákban a nevelés-oktatás digitális munkarendben kerül megszervezésre. Ezeknek a rendeleteknek a hatására és elővigyázatossági okokból terjedt el az otthoni munkavégzés, a HO.

HO alatt a hagyományos (teljes munkaidös, határozatlan idejü munkaszerződéses) munkaviszonyban foglalkoztatott munkavállaló számára ideiglenesen a munkáltató engedélyezi a munkáltató telephelyétől eltérő helyen való munkavégzést (Bankó 2020). Az otthonról történő munkavégzés, amelyhez rugalmas munkaidő is társulhat, mint elvárás a Z generáció kapcsán is megjelenik (Molnár 2016), mely generációt számos eltérő elnevezéssel illetnek. Ezek jól leírják a generáció bizonyos jellemzőit és azok bizonyos fokú kötődését a HO-hoz.

Kutatásunk fókuszában a COVID19 járvány HO-ra való hatásának vizsgálata áll a 2020. március és december közötti időszakra vonatkozóan a $Z$ generációs munkavállalók szempontjából 3 régió 1-1 kiválasztott megyeszékhelyének (Budapest, Pécs, Székesfehérvár) tekintetében. Célunk feltárni:

1) a HO időszaka alatt érzékelt teljesítményhez köthető tényezők közötti kapcsolatot,

2) az eltéréseket a HO munkavégzés általuk érzékelt előnyök és hátrányok TOP5 listájánál a földrajzi elhelyezkedés tekintetében,

3) a pozitív és negatív vélekedéseket föld- rajzi elhelyezkedés, végzettség és a munkáltató által elrendelt $\mathrm{HO}$ alkalmak száma alapján.

Pilot vizsgálatunk a fentieket figyelembe véve az alábbi kérdésekre keresi a választ a $Z$ generációs munkavállalókra fókuszálva:

K1: Milyen kapcsolat határozható meg a járvány előtti munkakezdés, a járványnak a mindennapi életre gyakorolt hatása, a $\mathrm{HO}$, mint jelenség iránti tetszés, a HO-nak a munkába járáshoz viszonyított preferenciája, valamint a HO alatti érzékelt teljesítmény között?

K2: Mutatkozik-e eltérés a földrajzi elhelyezkedés tekintetében a HO munkavégzéshez kapcsolódó érzékelt előnyök és hátrányok TOP5 listájának kialakításánál?

K3: Földrajzi elhelyezkedést, végzettséget és a munkáltató által elrendelt $\mathrm{HO}$ alkalmak számát figyelembe véve mutatkozik-e eltérés szentimentértékekben a HO-hoz való viszonynál?

Tanulmányunk további részét, a $\mathrm{Z}$ generáció bemutatásával folytatjuk. Majd ismertetjük a HO és a távmunka jellemzőit, az alkalmazott módszertant, és az eredményeket. Végezetül bemutatjuk a pilot kutatás korlátait és a jövőbeli kutatási irányokat.

\section{Z GENERÁCIÓ GENERATION Z}

Napjainkra a vállalatok felismerve a generációs megközelítés fontosságát, a tudományos szféra mellett, egyre inkább foglalkoznak a generációk közötti különbözőségekben rejlő lehetőségekkel (Pál et al. 2017). Érdemes kiemelni azt, hogy az „azonos generációba tartozás könnyítheti a munkakapcsolatot, gördülékenyebbé teheti az együttmüködést, hiszen az azonos generációjú emberek sajátos normarendszerrel, tapasztalatokkal, szokásokkal rendelkeznek" (Lukovszki 2015, 53). A szakirodalomban megtalálható generációk elnevezései és korszakolásai egymással többnyire átfedést mutatnak: érettek / érett generáció / veteránok / építők / csendes generáció (1920-1925-től 1945ig), baby bommerek / boom generáció (1946-től 1964-ig), X generáció (1965-től 1975-1980-ig), Y generáció (1976-1981-től 1994-2000-ig) és Z generáció / évezred utániak (1995-2001-től 2009-ig) (Oblinger \& Oblinger 2005, Tari 2011).

A Z generáció tagjait számos eltérő névvel illették, a digitális bennszülöttektől (Palfrey \& Gasser 2008, Jones \& Czerniewicz 2010) kezdve a kapcsolódott (Goodstein 2007) és a következö generáción át (Mysirlaki \& Paraskeva 2010) a net generációig (Tapscott 2008). A korábbi generációkhoz képest 
tagjai egy teljesen átalakult társadalmi és technológiai világban nőttek fel (Ferincz 2013). Így megemlíthető a lakhatás és önálló élet kérdése (mamahotel), az internet és a közösségi média túlzott használata, az online zaklatás veszélye, lexikális tudás helyett a megszerezhető ismeret praktikusságának előtérbe helyezése (Colorosa 2014, Kárpáti 2019, Twenge 2018). Erőteljesen elterjedt a közösségi oldalakon való kommunikációjuk (Bernschütz \& Pethes 2015). A generáció sajátosságai közé sorolható ugyanakkor a kapcsolódottság, azonnaliság, felszínesség, kényelmesség, kísérletező jelleg, szociális viselkedés, csapatjátékos viselkedés, bevonódás és tapasztalat iránti igény, vizualitás, kézzelfoghatóság, és a nagyon erős multi-tasking készségek is (Ferincz 2013, Konczosné 2017).

Potenciális munkavállalóként az internetnek köszönhetően a világ szinte bármely pontjáról elérhetők, így képesek onnan munkát vállalni feltéve, ha az adott munkakör lehetővé teszi (Kocsis 2017). A munka világával szembeni elvárásoknál az online lét által nyújtott lehetőségeket szintén megjelennek: HO, rugalmasság a munkaidő szabad beosztásával, munka és magánélet egyensúlya (Molnár 2016, Konczosné 2017, Garai-Fodor \& Jäckel 2018, Krajcsák 2018). Elvárásaikra jellemző még a közvetlen kapcsolat kialakítása főnökséggel a gyors elérhetőség és kérdések miatt; teljesítményük folyamatos és nyilvános elismerése és azonnali jutalom lehetősége; jó kapcsolat és közös programok lehetősége a munkatársakkal; minél több tapasztalat megszerzése; vállalati vérkeringésbe való bekapcsolódás; kihívást jelentő munka és kibontakozás lehetősége; karriervágy kiteljesedésének és szakmai ambíció lehetősége (Ferincz 2013, Tari 2015, Szabó-Szentrógi és tsai 2019). Továbbá 1-2, max 3-4 évet egyegy munkahelyen töltve, onnan bátran lépnek, ha az nem kielégítő már számukra, így a gyakori munkahelyváltás sem jelent nekik problémát (Cservenyák 2004, Kocsis 2017).

A munkahelyi elvárás tekintetében az alábbi kihívások emelhetők ki: saját korlátok ismeretének hiánya a teljesítményértékelésnél; túlzott önbizalom, értékek és önkép torzulása; elkötelezettségük növelését a hagyományos motivációs eszközök nem segítik elő; inkább konfliktus előidézők; nehezen türik a kötöttségeket; hosszabb ideig egy dologra történő koncentráció nehézsége (Smola \& Sutton 2002, Bencsik \& Machova 2016, Konczosné 2017, Krajcsák 2018).

\section{HOME OFFICE HOME OFFICE}

A HO, más néven otthoni munkavégzés nem új keletü jelenség, ennek ellenére nem sok vállalatnál alkalmazták. Ennek oka lehet a személyes kontroll hiánya által szült bizalmatlanság a munkáltatói oldalról. Azonban 2020 első negyedévében a COVID következtében számottevően megugrott ennek a munkavégzési formának az alkalmazása. A legtöbb cég a járvány által kiszabott korlátozások következtében vezette be az otthoni munkavégzést. Ugyan kényszerhelyzet szülte és a vállalatok a túléles érdekében vezették be, mégis hatalmas sikert aratott (Szabó 2020).

Peters et al. (2004) szerint az otthoni munkavégzés, azon munkafeladatok esetében a legmegfelelőbb, amelyek szellemi aktivitást igényelnek, világos célokkal rendelkezik, egyértelműen megfogalmazhatók, önállóan végezhetők, mérhető eredményeik vannak, valamint minimális közvetlen ellenőrzést igényelnek.

2018. I. negyedévében a KSH (2021a) felmérése szerint 96.000 dolgoztak ,home office” keretében. Ezzel szemben a 2020. I-IV. negyedévében vizsgáltak alapján a HO során a jellemzően otthonról dolgozók száma 163.107, alkalmanként otthonról dolgozók száma pedig 332.979 volt (KSH 2021b).

A KSH (2021c) adatai szerint a 2020. március és december között rendszeresen vagy alkalmanként HO-ban dolgozók aránya a járvány hullámaihoz hasonlóan végig ingadozott. A májusban elért csúcs $(17,2 \%)$ után folyamatosan csökkent egészen decemberig, amikor is 5,8\% volt az arány.

HO esetén a munkáltatónak kötelessége a munkavállalónak a munkaviszony teljesítésével járó költséget megtéríteni. Továbbá itt nem érvényesül a távmunkánál meglévő szabály, mely szerint a munkaidőt magának oszthatja be a munkavállaló (Kocsis 2020).

\section{HOME OFFICE ÉS TÁVMUNKA HOME OFFICE AND TELEWOR- KING}

Annak ellenére, hogy a HO és a távmunkavégzés (TMV) hasonló munkavégzési forma, mégsem összekeverendők. A Munka törvénykönyvéről szóló 2012. évi I. törvény 196. § (1) és (2) bekezdése szerint a TMV a felek által munkaszerződésben rögzített, a munkáltató telephelyétől elkülönült helyen rendszeresen folytatott tevékenység. A HO pedig egy eseti jellegű távmunka, ami egy speciá- 
lis munkaviszony és amit egyoldalúan is elrendelhet a munkaadó, továbbá a TMV-el szemben csak átmeneti időszakra vonatkozik (pl. veszélyhelyzet miatt elrendelt korlátozások megszünéséig) (Kocsis 2020). A vészhelyzet miatt azonban ez a különbség nem érvényesült, hiszen a 47/2020 (III. 18.) Korm. rendelet 6 . $\S(2)$ bekezdés b) pontja alapján a HO-t és a TMV-t is egyoldalúan elrendelheti a munkáltató.
Továbbá míg a TMV atipikus foglalkoztatási forma, azaz eltér a hagyományos heti 40 órás, határozatlan idejü, munkahelyen végzett munkaviszonytól, addig a HO inkább tipikus munkavégzésnek tekinthető, hiszen csak a munkavégzés helye tér el a tipikusnak nevezett foglalkoztatási formáktól (Herdon 2020). Az alábbi táblázatban (1. táblázat) összefoglaltuk a HO és a távmunka különbségeit.

1. táblázat: HO és a távmunka

Table 1. Home office and teleworking

\begin{tabular}{|c|c|c|}
\hline Jellemzők & Távmunka & Home office \\
\hline Helye & $\begin{array}{c}\text { teljes mértékben / } \\
\text { részlegesen otthon végzik }\end{array}$ & $\begin{array}{c}\text { munkáltató székhelyétől eltérő } \\
\text { helyen végzik }\end{array}$ \\
\hline Munkavégzés & rendszeres & ad hoc \\
\hline Létrejöhet (alap esetben) & $\begin{array}{c}\text { csak munkaszerződésben való } \\
\text { kikötés esetén }\end{array}$ & $\begin{array}{c}\text { nem kell munkaszerződésbe } \\
\text { foglalni }\end{array}$ \\
\hline Munkaidő & kötetlen & nem kötetlen \\
\hline Munka Törvénykönyv & szerepel benne & nincs külön nevesítve \\
\hline
\end{tabular}

Forrás: jogadó (2019) és érthetőjog (2020) alapján saját szerkesztés

Érdekesség, hogy a munkamánia (napi 10-14 óra munka) a HO-ban dolgozók jelentős részét érinti, és esetükben könnyebben alakulhat is ki (Kazainé 2020). Ugyanakkor Gaudecker et al. (2020) tanulmánya alapján a munkavégzéssel töltött órák szám a COVID megjelenése után 13\%-al csökkent. A járvány helyzet előtt a dolgozók 29 órát töltöttek a munkahelyükön munkával és 4 órát dolgoztak otthonról, a COVID hatására ez 50-50\%-ra változott.

A KSH (2021c) adataiból látszik, hogy az elmúlt tíz év átlagának (2,9\%) közel háromszorosára nőtt a TMV vagy HO keretében dolgozók aránya $(8,6 \%)$ hazánkban a 2020-as évben. 2020 májusába a foglalkoztatottak 17\%-a (kb. 760 ezer fó) dolgozott HO-ban.

\section{MÓDSZERTAN METHODOLOGY}

Pilot tanulmányunkban 3 feltételezést fogalmaztuk meg:

F1: A Z generációs munkavállalók járvány előtti munkakezdése, a járványnak a mindennapi életre gyakorolt hatása, a HO, mint jelenség értékelése, a HO-nak a munkába járáshoz viszonyított preferenciája, valamint a HO időszaka alatt érzékelt teljesítmény között kapcsolat határozható meg.

F2: Eltérés fedezhető fel a földrajzi elhelyezkedés tekintetében a $Z$ generációs munkavállalóknál a HO munkavégzés általuk érzékelt előnyök és hátrányok TOP5 listájának kialakításánál.

F3: Eltérés fedezhető fel a Z generációs munkavállalók $\mathrm{HO}-\mathrm{hoz}$ való viszonyánál a földrajzi elhelyezkedés, a végzettség és a munkaadó által elrendelt HO alkalmak száma alapján.

Az F1 feltételezés vizsgálatára kereszttábla elemzést használtunk, amely során arra keressük a választ, hogy két nominális vagy ordinális változó kapcsolatban áll-e egymással (Sajtos - Mitev 
2007). A Pearson-féle Khí-négyzet ( $\chi 2$ ) mutatószámot használtuk, amely két változó összefüggésének statisztikai szignifikanciáját méri és, amely segítségével megállapítható, hogy a változók között fennáll-e statisztikai összefüggés (Matthews \& Ross 2010). A kereszttábla elemzés nullhipotézisének elvetésekor (a vizsgálatba bevont változók között nincs összefüggés) meg kell vizsgálni a fennálló kapcsolat erősségét. A Phí együttható (2x2-es kereszttábla esetén) és a Cramer V mutató (bármely méretü kereszttábla esetén) minél közelebb áll az 1 értékhez, annál erősebb a kapcsolat a változók között.

F2 feltételezés kapcsán a $Z$ generációs munkavállalóknak a $\mathrm{HO}$ előnyeire és hátrányaira vonatkozó kérdésekre adott válaszaikat csoportba szedtük meghatározva azok számosságát és listáztuk a TOP5 leggyakrabban említett előnyt, illetve hátrányt. Majd a földrajzi elhelyezkedés szempontjából összehasonlítást végeztünk.

Az F3 feltételezés során szentimentelemzéssel megállapítottuk, hogy milyen érzelmi polaritás jellemzi a Z generációs munkavállalókat a $\mathrm{HO}$ kapcsán. A „sentiment analysis” vagy más néven „opinion mining”, magyarul érzelemelemzés segítségével elemezni tudjuk a megkérdezettek véleményét, érzéseit és hozzáállásukat (Liu 2012).

\section{EREDMÉNYEK RESULTS}

Annak érdekében, hogy megválaszoljuk a feltett kérdéseket és teszteljük a feltételezéseket a HO-al kapcsolatban kérdőives kutatást végeztünk a $Z$ generációs fiatalok körében 2021. februárjában. A kérdőívböl 140-et küldtünk ki az általunk kiválasztott 3 régió (Közép-Magyarország, Közép-Dunántúl és Dél-Dunántúl) 1-1 megyeszékhelyén élő (Budapest, Pécs, Székesfehérvár) fiataljainak.
Ezekben a régiókban igen magas volt a $\mathrm{HO}$ aránya: a fővárosban 2019-ben 5,4\%, 2020-ban 21,3\%, Közép-Dunántúlon 2019-ben $\quad 0,6 \%$, 2020-ban 4,2\% és Dél-Dunántúlon 2019-ben 0,9\%, 2020ban 5,2\%-re nőtt a HO-ban foglalkoztatottak száma (KSH 2021c).

Ahhoz, hogy plasztikusabb képet kapjunk arról, hogy hogyan vélekednek erröl a $Z$ generációs munkavállalók a HO-ról, összeállítottunk egy 4 kérdéscsoportból és 33 kérdésből álló anonim, online kérdőívet. Jelen tanulmányhoz a $Z$ generációs munkavállalók általános adataira kitérő kérdéseket és a HO munkavállalóra gyakorolt hatására vonatkozó kérdéseket használtuk fel.

Összesen 140 személy töltötte ki a kérdőívet, akiket középiskolai ALUMNI és felsőoktatási intézmények csoportjain keresztül értünk el. Ebből 118 kérdőív bizonyult értékelhetőnek (válaszadási arány: 84,3\%). A kitöltők születési éve 1995 és 2002 közöttre tehető, 59\%-a (70 fö) nő és $41 \%$-a férfi (48 fö) volt. Lakhelyüket tekintve 52 fö (44\%) Budapesten, 33 fö (28\%) Pécsett és 33 fö (28\%) Székesfehérváron dolgozik és/vagy lakik. Végzettségüket tekintve, míg 51\%-uk (60 fö) középfokú iskolai érettségivel, addig 49\%-uk (58 fö) alapvagy mesterszakos diplomával rendelkezik.

\section{Kereszttábla elemzés Crosstab analysis}

Az F1 feltételezéshez kapcsolódó kereszttábla elemzés elvégzésénél az egyik fő szempont az volt, hogy a lehető legtöbb válasz kerüljön egy-egy kategóriába a kereszttábla változói kapcsán, így a kérdőív adott kérdésre vonatkozó válaszait volt, hogy össze kellett vonnunk. Ennek következtében egy modellben kerülnek megjelenítésre a kapcsolatok erősségét leíró Cramer illetve Phi értékeket tartalmazó eredmények az 1 . ábrában.

\section{1. ábra: Modell eredményekkel \\ Figure 1. Model with results}

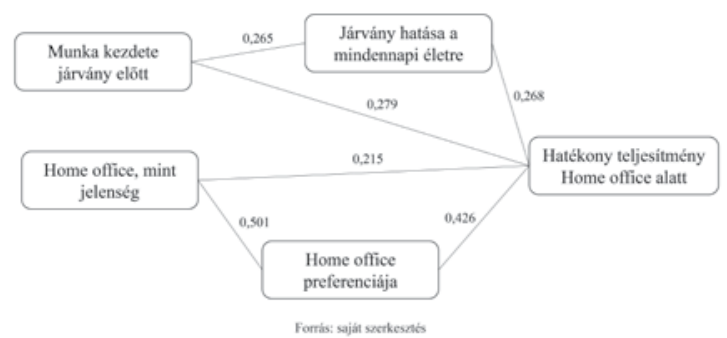

Forrás: Saját szerkesztés 
Az alábbi kapcsolatok mindegyike közepes kapcsolatot takar:

- Mikor kezdtek el dolgozni a járvány kitörése elött és mennyire hatott negatívan a mindennapi életükre a járvány $(\chi 2=8,280$, $\mathrm{df}=3, \mathrm{p}=0,04$, Cramer $\mathrm{V}=0,264)$.

- Mikor kezdtek el dolgozni a járvány kitörése előtt és saját megítélésük szerint mennyire hatékonyan teljesítettek a $\mathrm{HO}$ alatt $(\chi 2=9,228, \mathrm{df}=3, \mathrm{p}=0,02$, Cramer $\mathrm{V}=$ $0,279)$.

- Mennyire hatott a mindennapi életükre a járványa és saját megítélésük szerint mennyire hatékonyan teljesítettek a $\mathrm{HO}$ alatt $(\chi 2=8,489, \mathrm{df}=3, \mathrm{p}=0,03$, Cramer $\mathrm{V}=$ $0,268)$.

- Mennyire tetszik nekik a HO, mint jelenség és saját megítélésük szerint menynyire hatékonyan teljesítettek a $\mathrm{HO}$ alatt $(\chi 2=5,458, \mathrm{df}=1, \mathrm{p}=0,01, \mathrm{Phi}=0,215)$.

- $\quad$ A HO, mint jelenség pozitív értékelése és a HO-nak a munkába járáshoz viszonyított preferenciája $(\chi 2=29,591, \mathrm{df}=1, \mathrm{p}=0,00$, Phi=0,501).

- Mennyire preferálják a HO-t a munkába járáshoz viszonyítva és saját megítélésük szerint mennyire hatékonyan teljesítettek a $\mathrm{HO}$ alatt $(\chi 2=21,370, \mathrm{df}=1, \mathrm{p}=0,00, \mathrm{Phi}=$ 0,426).

Az elemzés ugyanakkor nem mutatott ki szignifikáns kapcsolat a 'Munka kezdete járvány előtt' és a 'HO, mint jelenség', a 'Munka kezdete járvány előtt' és a 'HO preferenciája', a 'Járvány hatása a

mindennapi életre' és a 'HO, mint jelenség' valamint a 'Járvány hatása a mindennapi életre' és a 'HO preferenciája' kapcsolatokat illetően.

Tehát az F1 feltételezés csak részben került elfogadásra, mert néhány vizsgált elem között nem tártunk fel kapcsolatot.

\section{HO TOP5 előnye és hátránya TOP5 advantages and disadvantages of $\mathrm{HO}$}

Az F2 feltételezésnél a régióként elemeztük a HO előnyeit és hátrányait a $Z$ generációs munkavállalókra nézve. Összegyüjtöttük az 5 leggyakrabban említett (TOP5) előnyt és hátrányt. A két vizsgált csoport (Budapest és Pécs-Székesfehérvár) kapcsán nem mutatkozik különbség a HO előnyeinek TOP5 sorrendjében (2. táblázat).

A ,bezártság és elhidegülés érzése' és a ,motiváció/morál csökkenése', valamint a 'hatékonyság csökkenése, nehezebb koncentráció' mindkét listán szerepelnek, azonban eltérö helyezést értek el. Eltérést Budapest esetén az utolsó előtti helyre kerülő ,nehezebb időbeosztás, munka-magán élet egybefolyása', Pécs és Székesfehérvár kapcsán a 2. helyen szereplő ,nehezebb kommunikáció' jelenti (3. táblázat).

Az F2 feltételezést szintén részben elfogadtuk, mert a HO munkavégzés $Z$ generációs munkavállalók által érzékelt előnyeinek TOP5 listájának kialakításánál nem, míg a hátrányok tekintetében volt eltérés.

2. táblázat: TOP5 HO előny

Table 2. TOP5 Home office advantage

\begin{tabular}{|c|c|}
\hline TOP & Budapest, Pécs, Székesfehérvár \\
\hline 1 & utazási költség/ idő csökkentés \\
\hline 2 & kötetlen, rugalmas munkaidő \\
\hline 3 & kényelem/ nyugodtabb környezet \\
\hline 4 & több szabadidö \\
\hline 5 & hatékonyabb munkavégzés \\
\hline
\end{tabular}

Forrás: Saját szerkesztés 
3. táblázat: TOP5 HO hátrány

Table 3. TOP5 Home office disadvantage

\begin{tabular}{|c|c|c|}
\hline TOP & Budapest & Pécs - Székesfehérvár \\
\hline 1 & \multicolumn{2}{|c|}{ személyes kapcsolatok megszünése/ hiánya } \\
\hline 2 & bezártság és elhidegülés érzése & nehezebb kommunikáció \\
\hline 3 & $\begin{array}{r}\text { hatékonyság csökkenése, nehezebb kon- } \\
\text { centráció }\end{array}$ & motiváció/ morál csökkenése \\
\hline 4 & $\begin{array}{r}\text { nehezebb időbeosztás, munka magán élet } \\
\text { egybefolyik }\end{array}$ & $\begin{array}{r}\text { hatékonyság csökkenése, nehezebb kon- } \\
\text { centráció }\end{array}$ \\
\hline 5 & motiváció/ morál csökkenése & bezártság és elhidegülés érzése \\
\hline
\end{tabular}

Forrás: Saját szerkesztés

\section{Szentimentelemzés Sentiment analysis}

Az F3 feltételezésnél szentimentelemzést alkalmaztunk a korpuszon, hogy meg tudjuk vizsgálni a Z generációs munkavállalók a HO-ról való vélekedését. A különböző kérdésekre adott szöveges válaszok alapján megállapítottuk, hogy ki hogyan véle- kedik a HO-ról. A korpuszban megvizsgáltuk, hogy hány negatív és hány pozitív polaritású jellemzőt említettek a válaszadóink a $\mathrm{HO}$ kapcsán. Ezeket összegezve megkaptuk mindegyik kitöltőnek a szentiment értékét. A kapott értékeket kategorizáltuk negatív, pozitív és semleges jellegük szerint. Eredményként megkaptuk mindegyik válaszadó érzelmi polaritását a HO kapcsán (4. táblázat).

4. táblázat: Városonkénti, Végzettség és HO elrendelése száma szerinti szentiment értékek Table 4. Sentiment values by cities, education and number of HO ordered

\begin{tabular}{|c|c|c|c|}
\hline Város & pozitív & negatív & semleges \\
\hline Budapest & $46,2 \%$ & $40,3 \%$ & $13,5 \%$ \\
\hline Pécs & $51,5 \%$ & $36,4 \%$ & $12,1 \%$ \\
\hline Székesfehérvár & $54,6 \%$ & $24,2 \%$ & $21,2 \%$ \\
\hline \multicolumn{4}{|l|}{ Végzettség } \\
\hline $\mathrm{BSc} \& \mathrm{MSc}$ & $41,4 \%$ & $41,4 \%$ & $17,2 \%$ \\
\hline Érettségi & $58,3 \%$ & $28,3 \%$ & $13,3 \%$ \\
\hline \multicolumn{4}{|l|}{ HO elrendelése } \\
\hline egyszer & $57,6 \%$ & $33,3 \%$ & $9,1 \%$ \\
\hline kétszer vagy többször & $40,4 \%$ & $36,5 \%$ & $23,1 \%$ \\
\hline
\end{tabular}

Forrás: Saját szerkesztés 
Városonként megvizsgálva a kapott szentiment értékeket megfigyelhető, hogy a fóvárosban kevésbé vélekednek pozitívan a HO-ról, mint a másik két városban. A legpozitívabban a Székesfehérváron élők nyilatkoztak a HO-ról, 54,55\%-uk kedveli ezt a foglalkoztatási fajtát.

Megállapítottuk, hogy azok, akinek az érettségi a legmagasabb végzettsége, azok sokkal pozitívabban $(58,33 \%)$ viszonyulnak a $\mathrm{HO}-$ hoz, mint akiknek BSc vagy MSc (41,38\%) a legmagasabb képesítése. Továbbá akik felsőfokú oklevéllel rendelkeznek, azoknál ugyanannyian vélekedtek pozitívan és negatívan a HO-ról.

Akiknél csak egyszer rendelték el a HO-t, azok sokkal pozitívabban vélekednek róla, mint akiknél többször is bevezetésre került. Azoknál, akik többször is HO-ba kényszerültek nagyobb a negatív és a semleges vélekedések aránya.

Az F3 feltételezés megerősítésre került, mivel eltérés mutatkozik földrajzi elhelyezkedés, végzettség és az elrendelt HO alkalmak száma alapján a Z generációs munkavállalók HO-hoz való érzelmi viszonya tekintetében.

\section{KÖVETKEZTETÉSEK ÉS KOR- LÁTOK DISCUSSION AND LIMITATIONS}

A pilot vizsgálat eredményei rávilágítottak arra, hogy a járvány kitörését megelőzően a szervezetnél eltöltött idő és a járványnak a mindennapi életre való (negatív) hatása között kapcsolat van. Továbbá ezek külön-külön is kapcsolatban állnak a $Z$ generációs munkavállalók általuk megfigyelt teljesítményváltozásával. Különösen a rövid idejü munkatapasztalattal rendelkező $\mathrm{Z}$ generációs fiataloknak kihívás teljesíteni az olyan kompetenciaelvárásokat, mint az alapvető munkavállalói, feladat-megoldási, kommunikációs, együttmüködési vagy éppen alkalmazkodási kompetenciák (Tóthné \& Hlédik 2018, Tóthné \& Kelemen-Erdős 2020). A Z generáció tagjainak jobb munkahelyi teljesítményét az innovatív és kreativitást igénylő megoldások alkalmazása segítheti elő (Bencsik és tsai 2017).

Akiknek tetszett a HO, azok többségében preferálták is ezt a munkavégzést a hagyományos munkába járáshoz képest. $\mathrm{A} \mathrm{Z}$ generációs fiatalok $\mathrm{HO}$ iránti preferenciája, valamint tetszése külön-külön is hatékonyabb teljesítményt idéz elő. A HO, mint elvárás korábban is megjelent a $\mathrm{Z}$ generáció kap- csán (Molnár 2016), ugyanakkor annak teljesítménnyel kapcsolatos összefüggéseire felmérésünk tett kísérletet.

A HO előnyeiről hasonlóan vélekednek a $Z$ generációs munkavállalók a vizsgált régiókban. Legfontosabb előnynek az utazási idő és költség csökkenését tartják. Ezzel szemben Lipták (2020) felmérése alapján a nagyobb szabadság a HO-hoz köthető legfontosabb pozitívum. Ugyanakkor a kötetlen, rugalmas munkaidő lehetőségét és a részben, ezáltal elérhető kényelmes, nyugodtabb környezetet is sokat. Részben a kereszttábla elemzéssel átfedésben, előnyként a hatékonyabb munkavégzést és az ezáltal elérhető több szabadidő is belekerült a TOP5 legfontosabb előnybe.

A HO által generált negatívumok tekintetében már sokkal nagyobb különbségek figyelhetők meg a vizsgált régiók között. Egységesen a kapcsolatok csökkenését, illetve hiányát, mint hátránnyal egyetértenek. Gajendran és Harrison (2007) negatív kapcsolatot fedezett fel a munkatársi kapcsolat és a $\mathrm{HO}$ minősége között: a vezetők és az alkalmazottak esetében is a fizikai távollétnek köszönhetöen csökken a munka koordináció és a csapatként való együttmüködés lehetősége. A fövárosban ugyanakkor jobban jelen van az elhidegülés, bezártság érzése, a koncentrációs nehézségek, munka és magánélet egybefolyása. Ezt részben alátámasztja, hogy itt sokkal negatívabban viszonyulnak a HO-hoz, mint Pécsett vagy Székesfehérváron. Ezen városokban dolgozók körében a koncentrációs nehézségek és a hatékonyság csökkenése mellett az elhidegülés és a bezártság érzése is jelen van, valamint a kommunikációs nehézségek és a motiváció csökkenése is sokkal jobban megjelenik. A motiváció megörzéséhez, Pirohov-Tóth és tsai (2020) szerint, a jól megfogalmazott konkrét elvárások, a megfelelő tájékoztatás és infrastruktúra is hozzájárulhat.

Szentimentelemzés során világossá vált, hogy a fővárosban lakó és dolgozó munkavállalók negatívabban vélekednek a HO-ról, mint a másik 2 megyeszékhelyen élők. Továbbá a végzettség is szerepet játszik a HO-hoz való hozzáállásban, mivel a felsőfokú végzettséggel rendelkezőknek kevésbé tetszik a HO összehasonlítva azzal, akinek a legmagasabb végzettsége az érettségi. Ellenben Bick et al. (2020) tanulmánya szerint a képzettebb munkavállalók nagyobb valószínüséggel képesek otthonról dolgozni. Feltártuk továbbá, hogy akiknél csak egyszer rendelték el a HO-t, pozitívabban vélekednek róla, mint akiknél többször is bevezetésre került. 
A felmérés eredményei korlátozottan alkalmasak messzemenő következtetések levonására, mivel a vizsgált 3 régióban élő és dolgozó foglalkoztatottak / Z generáció létszámához képest a kisszámú a minta. Pilot tanulmányként ez további mélyreható vizsgálatot igényel nagyobb kutatási mintán, további régiók kutatásba történő bevonásával. Továbbá ki lehetne terjeszteni és össze lehetne hasonlítható a $Z$ generációra vonatkozó eredményeket más pl. Y generáció eredményeivel is.

\section{ÖSSZEFOGLALÁS SUMMARY}

Pilot tanulmányunk a COVID19 által elöidézett HO jelenséget vizsgálta a $\mathrm{Z}$ generációs munkavállalók nézőpontjából 3 régió tekintetében. Felmérésünk a HO munkavégzés alatt érzékelt teljesítménnyel kapcsolatos tényezök közötti kapcsolat feltárását, a HO munkavégzéshez kapcsolódó munkavállalói előnyök és hátrányok TOP5 listájában mutatkozó eltérések földrajzi elhelyezkedésből adódó különbségeinek azonosítását, valamint földrajzi elhelyezkedés, végzettség és a munkáltató által elrendelt HO alkalmak száma alapján a pozitív és negatív vélekedések feltárását célozta és vizsgálta meg. A 2021. februárjában végzett kérdőíves felmérés során 3 régió 1-1 megyeszékhelyén élő (Budapest, Pécs, Székesfehérvár) 118 Z generációs fiatal 2020. március és december közötti időszakra vonatkozó HO tapasztalatait vizsgáltuk, amelyekből származó adatokon kereszttábla és szentiment elemzés mellett, TOP5 sorrend kialakítását és összehasonlítását is elvégeztük. A pilot kutatás korlátai miatt messzemenő következtetések nem kerülhettek levonásra, azonban további kutatási irányokat megfogalmaztunk.

\section{HIVATKOZÁSOK REFERENCES}

Bankó, Z. (2020), Az atipikus munkajogviszonyok in: Kiss, Gy. (eds.): Munkajog, Budapest: Ludovika, 335-363

Barrot, J.N., Grassi, B. and Sauvagnat, J. (2021), "Sectoral effects of social distancing", AEA Papers and Proceedings, 111(5), 277-281. DOI: 10.1257/pandp.20211108

Bencsik, A., Horváth-Csikós, G. and Juhász, T. (2017), „Az Y és a $Z$ generációval szembeni elöíteletek a munkahelyen", Taylor, 9(2), 121128.

Bencsik, A. and Machova, R. (2016), "Knowledge Sharing Problems from the Viewpoint of Intergeneration Management", in: ICMLG2016 Conference, Reading: ACPI, 42-48

Bernschütz, M. and Pethes, B. (2015), „A digitális birkatudat nyomában- $Z$ generációs kommunikációs viselkedési minta", Marketing \& Menedzsment, 49(3), 68-79

Bick, A., Blandin, A. and Mertens, K. (2020), Work from home after the COVID-19 outbreak. Working paper. DOI:10.24149/wp2017r1

Colorosa, B. (2014), ,Zaklatók, áldozatok, szemlélődők: Az iskolai erőszak", Budapest: Harmat

Cservenyák, T. (2004), Váltani kell? Álláskeresés és karrierváltás Magyarországon, Budapest: Kossuth

Ferincz, A. (2013), „Az új generáció elvárásai a munkahelyekkel szemben", Ekonomické Štúdie- Teória a Prax, 220-228.

Garai-Fodor, M. and Jäckel, K. (2018), „Kvalitatív kutatási eredmények a $\mathrm{Z}$ generáció körében: Milyen karrierről álmodnak, milyen munkahelyen dolgoznának szívesen a „Z”-k”, Vállalkozásfejlesztés a XXI. században. Budapest. 1. kötet, 70-80

Gaudecker, H.M., Holler, R., Janys, L., Siflinger, B. and Zimpelmann, B. (2020), ,Supply in the early stages of the COVID-19 pandemic: Empirical evidence on hours, home office, and expectations", IZA Discussion Paper No.13158.

Gajendran, R.S. and Harrison, D.A. (2007), "The good, the bad and the unknown about telecommuting: Meta-analysis of psychological mediators and individual consequences", Journal of Applied Psychology, 92(6), 1524-1541

Goodstein, A. (2007), Totally wired: What teens and tweens are really doing online. New York: Saint Martin's Griffin.

Jones, C. and Czerniewicz, L. (2010), "Describing or debunking? The net generation and digital natives", Journal of Computer Assisted Learning, 26(5), 317-320. DOI:10.1111/j.13652729.2010.00379.x 
Herdon, I. (2020), Fontos elhatárolás: Távmunka vagy home office jellemezte a járványügyi veszélyhelyzetet?, https://arsboni.hu/fontos-elhatarolas-tavmunka-vagy-home-office-jellemezte-a-jarvanyugyi-veszelyhelyzetet/ (Utolsó letöltés: 2021.01.26.)

Kazainé Ónodi, A. (2020), A távmunka jövője. A távmunkában rejlő lehetőségek az alkalmazottak véleménye alapján. Mühelytanulmány. Budapesti Corvinus Egyetem, Budapest. http:// unipub.lib.uni-corvinus.hu/5716/ (Utolsó letöltés: 2021.09.01.)

Kárpáti, L. (2019), „Gondolatok a Z-generáció társas jellemzőiről és ezek lehetséges társadalmi hatásairól", Közelitések. 6(3-4), 77-91

Kocsis, A (2017), „Z-generáció társadalmi kihívásai, avagy hogyan alkalmazkod(j)unk a jövö fiataljaihoz?", in: Torgyik, J (eds.): Válogatott tanulmányok a társadalomtudományok köréböl, Komárno: International Research Institute, 151159

Kocsis, I. (2020), Home office és távmunka: A kettő ugyanaz vagy különbözik? https://erthetojog. hu/munkajog/home-office-es-tavmunka-a-ketto-ugyanaz-vagy-kulonbozik (Utolsó letöltés: 2021.02.06.)

Konczosné, Sz.M. (2017), „Munkahelyek, irodák, generációk és nemek: Hogyan alkalmazkodik a munkahelyek építészete a generációs és nemi elvárásokhoz?", Társadalmi Nemek Tudománya Interdiszciplináris eFolyóirat, 7(1), 90-106.

Krajcsák, Z. (2018), „Az alkalmazotti elkötelezettség relatív fontossága a munka megváltozó világában", Vezetéstudomány, 49(2), 38-44. DOI:10.14267/veztud.2018.02.04

KSH (2020), Munkanélküliségi gyorstájékoztató, http://www.ksh.hu/docs/hun/xftp/gyor/mun/ mun2007.html (Utolsó letöltés: 2021.09.02.)

KSH (2021a), Távmunka és ,home office”, https:// www.ksh.hu/docs/hun/xftp/idoszaki/munkerohelyz/tavmunka/index.html (Utolsó letöltés: 2021.02.23.)

KSH (2021b), KSH 9.17.5. A 15-74 éves foglalkoztatottak távmunkavégzése munkaeröpiaci jellemzöik szerint, https:/www.ksh.hu/docs/hun/ xstadat/xstadat_evkozi/e_tavmunk9_17_05j. html (Utolsó letöltés: 2021.01.15.)

KSH (2021c), Felértékelődött a távmunka a Covid19 árnyékában, https://www.ksh.hu/docs/ hun/xftp/idoszaki/koronavirus-tavmunka/index. html (Utolsó letöltés: 2021.08.31.)

Lipták, K. (2020), „Maradj otthon, dolgozz otthon! - A koronavírus-járvány hatása a távmunkára Észak-Magyarországon, 2020. április”, Területi statisztika, 61(2), 153-169. DOI:10.15196/ TS610202

Liu, B. (2012), Sentiment analysis and opinion mining, Chicago: Morgan \& Claypool
Lukovszki, L. (2015), „Generációk és vállalkozók”, Marketing \& Menedzsment, 49(4), 52-63

Magyar Közlöny (2020), 47. sz. 47/2020 (III. 18.) Korm. Rendelete a koronavírus világjárvány nemzetgazdaságot érintő hatásának enyhítése érdekében szükséges azonnali intézkedésekről

Magyar Közlöny (2020), 56. sz. 71/2020 (III. 27.) Korm. Rendelete a kijárási korlátozásról

Magyar Közlöny (2020), 40/2020. (III. 11.) Korm. Rendelete a vészhelyzet kihirdetéséröl

Munka törvénykönyv (2012), 2012. évi I. törvény 196. $\S$

Matthews, B. and Ross, L. (2010), Research methods: A particular guide for the social sciences, Essex: Pearson

Molnár, B. (2016), „Új generációk a munkahelyeken: ezek a fiatalok!" $H V G, 38(7), 50$

Mysirlaki, S. and Paraskeva, F. (2010), "Online Games for the Next Generation of Workers", International Journal of Advanced Corporate Learning, 3(4), DOI:10.3991/ijac.v3i4.1401

Oblinger, D. and Oblinger, J.J. (2005), Educating the net generation, Washington: Educase

Pál, E., Töröcsik, M. and Jakopánecz, E. (2017), „Eltérő életkori lehatárolásokból adódó generációk értékeinek empirikus vizsgálata", Marketing \& Menedzsment, 51(3), 18-32

Palfrey, J. and Gasser, U. (2008): Born digital: Understanding the first generation of digital natives, New York: Basic Books

Peters, P., Tijdens, K.G. and Wetzels, C. (2004), 'Employees' opportunities, preferences, and practices in telecommuting adoption", Information and Management, 41(4), 469-82

Pirohov-Tóth, B. and Kiss Zs. (2020), „A munkaerő-piaci szereplők által tapasztalt foglalkoztatási kihívások a koronavírus-járvány idején", Opus et Educatio, 7(4), 402-409. DOI:10.3311/ ope. 408

Sajtos, L., Mitev, A. (2007), SPSS kutatási és adatelemzési kézikönyv, Budapest: Alinea

Smola, K.W. and Sutton, C.D. (2002), "Generational differences: Revisiting generational work values for the New Millenium". Journal of Organizational Behavior, 23(4), 363-382

Susskind, D. and Vines, D. (2020), "The economics of the COVID-19 pandemic: An assessment", Oxford Review of Economic Policy, 36(1), S1S13, DOI:10.1093/oxrep/graa036

Szabó, M.A. (2020), Home Office - a vírus előtt és alatt, https://ado.hu/munkaugyek/homeoffice-a-virus-elott-es-alatt (Utolsó letöltés: 2021.01.15.)

Szabó-Szentgróti, G., Gelencsér, M., Szabó-Szentgróti, E. and Berke, S. (2019), „Generációs hatás a munkahelyi konfliktusokban", Vezetéstudomány, 50(4), 77-88. DOI:10.14267/ veztud.2019.04.07 
Tapscott, D. (2008), Grown up digital: How the net generation is changing your world, New York: McGraw-Hill

Tari, A. (2011), Z generáció, Budapest: Tericum

Tari, A (2015), Generációk online, Budapest: Tercium

Tóthné T.T. and Kelemen-Erdős, A. (2020), „Pályakezdőkkel szembeni kompetenciaelvárások és mérésük", Marketing \&
Menedzsment, 54(1), 43-54. DOI:10.15170/ mm.2020.54.01.04

Tóthné, T.T. and Hlédik, E. (2018), „Kompetenciaelvárások értelmezése egy mélyinterjús kutatás eredményei alapján", Marketing \& Menedzsment, 52(2), 59-68

Twenge, J.M. (2018), iGeneráció - akik közösségi médián és okostelefonon nevelkedtek, Budapest: Édesvíz

Csepregi Anikó, $\mathrm{PhD}$, egyetemi docens csepregi.aniko@gtk.uni-pannon.hu

Pannon Egyetem Gazdaságtudományi Kar

Csanády Bettina, hallgató, gazdaságinformatikus Pécsi Tudományegyetem

\section{Generation Z and Home Office Work in 2020 during COVID19 - Pilot study results}

\section{THE AIMS OF THE PAPER}

The study focuses on COVID19's impact on home office work (HOW) from Generation Z's (GenZ) viewpoint between March and December 2020 in 3 regions. Our pilot study's aim is to explore the 1) connection between the affecting factors of perceived performance of employees during HOW, 2) differences between the list of TOP5 advantages and disadvantages of HOW based on different geographical locations, (3) employees' viewpoint on HOW based on geographical location, education and the amount of HOW demanded.

\section{METHODOLOGY}

Our pilot study was based on a survey conducted in February 2021 among 118 GenZ employees in 3 regions' selected county capitals (Budapest, Pécs, Székesfehérvár) to examine the HOW experiences for the above mentioned period. Besides crosstabs test and sentiment analysis conducted on the dataset, TOP5 raking was created and compared.

\section{MOST IMPORTANT RESULTS}

The pilot study found connection between influencing factors of perceived performance during the HOW period. No differences appeared regarding the TOP5 HOW advantages compared to disadvantages where more significant differences were revealed in the comparison of regions. Positive opinion on HOW was found mainly in Székesfehérvár and Pécs, among those with a secondary school-leaving certificate and having been ordered to do HOW only once. Negative opinion appeared in Budapest, among those with a graduate or masters degree and who did HOW on more than one occasion.

\section{RECOMMENDATIONS}

The pilot study results allow for further investigation and a better understanding of GenZ employees' behaviour during HOW. However they are still limited for extensive recommendations. As a future research direction the study sample could be increased by expanding it on other regions and comparing GenZ employee's results with other generations (e.g. Generation Y).

Keywords: COVID, home office, crosstab test, sentiment analysis, Generation Z 